\title{
Working
}

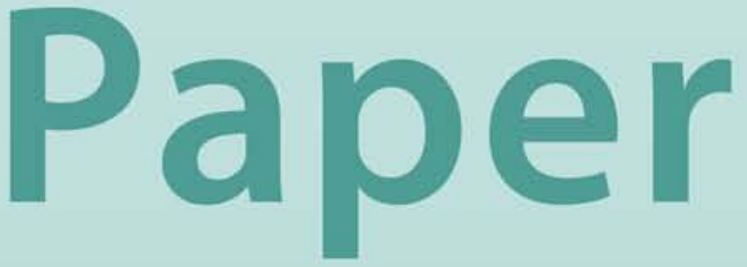




\section{Inflation Targeting and Monetary Policy Transmission Mechanisms in Emerging Market Economies}

Sanchita Mukherjee and Rina Bhattacharya 


\title{
IMF Working Paper
}

Middle East and Central Asia Department

\section{Inflation Targeting and Monetary Policy Transmission Mechanisms in Emerging Market Economies}

\author{
Prepared by Sanchita Mukherjee and Rina Bhattacharya
}

Authorized for distribution by Cheng Hoon Lim

October 2011

\begin{abstract}
This Working Paper should not be reported as representing the views of the IMF. The views expressed in this Working Paper are those of the author(s) and do not necessarily represent those of the IMF or IMF policy. Working Papers describe research in progress by the author(s) and are published to elicit comments and to further debate.
\end{abstract}

In this paper we empirically examine the operation of the traditional Keynesian interest rate channel of the monetary policy transmission mechanism in five potential inflation targeting economies in the MENA region and compare it with fourteen inflation targeting (IT) emerging market economies (EMEs) using panel data analysis. Contrary to some existing studies, our empirical results suggest that private consumption and investment in both groups of countries are sensitive to movements in real interest rates. Moreover, we find that the adoption of IT did not significantly alter the operation of the interest rate channel in IT EMEs. Also, the interest rate elasticities of private consumption and private investment vary with the level of development of the domestic financial market. Finally, capital account liberalization have opposite effects on private consumption and private investment in the two groups of countries.

JEL Classification Numbers: E21, E42, E44, E52, F41, F42

Keywords: Inflation targeting; private consumption; private investment; monetary policy; interest rate elasticity; financial market development

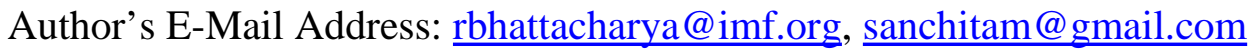




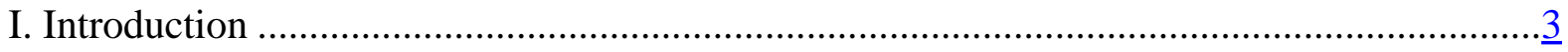

II. Channels Through Which Monetary Policy Can Affect Aggregate Demand ....................... $\underline{5}$

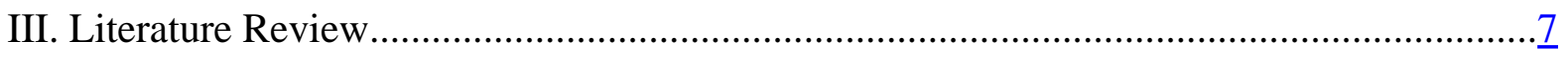

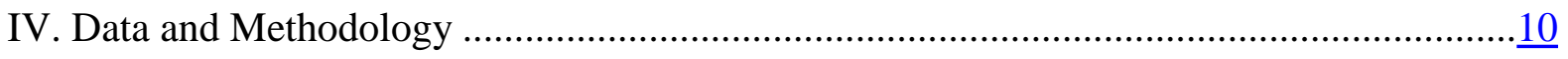

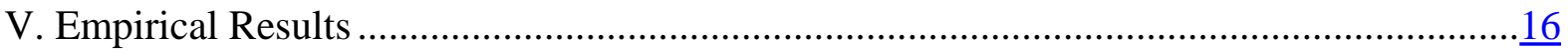

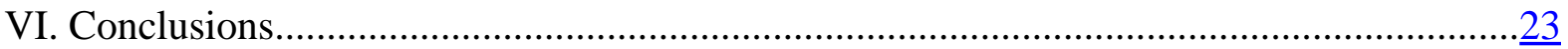

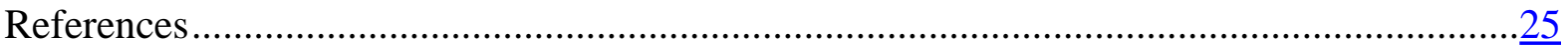

Tables

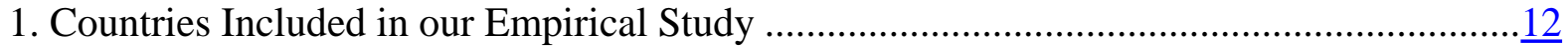

2. Data Sources of the Variables Used in our Empirical Study .........................................13

3. Summary Statistics of the Variables Used in our Empirical Study .................................14

4. Stationarity Test Results ..................................................................................... 15

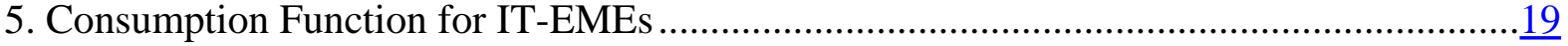

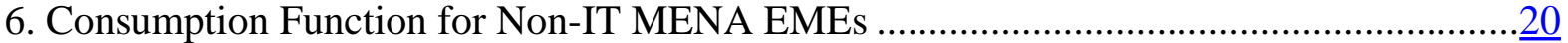

7. Investment Function for IT-EMEs.....................................................................

8. Investment Function for Non-IT MENA-EMEs .........................................................22

Figures

1. Interest Rate Elasticity of Private Consumption and Financial Development Index in Inflation Targeting Emerging Market Economies 


\section{INTRODUCTION}

A growing number of emerging market economies are moving towards inflaton targeting as the guiding framework for monetary policy actions. Inflaton targeting (IT) involves targeting inflation directly, in contrast to alternative strategies that seek to achieve low and stable inflation through targeting intermediate variables-for example, the growth rate of money aggregates or the level of the exchange rate of an 'anchor' currency. At present twenty-six countries can be classified as inflation targeters (Roger 2010), including nine industrial countries and seventeen emerging market and developing economies. In the MENA region, Turkey adopted IT in 2006, while Egypt, Tunisia and Morocco intend to move toward a fully fledged inflation targeting regime in the foreseeable future.

Not enough is known about the monetary policy transmission mechanism in the MENA region, and existing empirical studies sometimes give conflicting results. The literature to date emphasizes four key transmission channels - the traditional interest rate channel; the credit or loan supply channel; the exchange rate channel; and the asset price channel (see below). However, due to the poor quality of data in general and the fact that there is considerable variation in economic significance and informational content of the data on real rates of return, there has not been many empirical studies to determine the interest rate channel, especially the impact of the interest rate on private consumption and investment in IT emerging market economies and non-IT MENA economies.

There are various stages in the monetary policy transmission process. Under inflaton targeting the key monetary policy instrument is the short-term interest rate. The first stage of the transmission process is when changes in the policy rate leads to movements in retail interest rates, that is commercial bank deposit and lending rates. The second stage of the transmission process occurs through the impact of changes in these retail rates on private consumption and investment, and thereby on aggregate demand. In the third stage changes in aggregate demand affect the level of activity in the domestic economy, which in turn should have the desired effect on the inflation rate in the final stage of the monetary policy transmission process.

A sound understanding of the monetary policy transmission mechanism is a prerequisite for the successful adoption of inflaton targeting. Monetary policy transmission mechanisms (MTMs) can be defined as the processes by which changes in monetary policy decisions affect the rate of economic growth and/or the inflation rate (Taylor 1995). Under IT changes in the short-term interest rate affect aggregate demand and inflation through a large set of variables, including the real cost of capital, availability of bank credit, the exchange rate, household and corporate balance sheets, wealth and monetary aggregates. The transmission mechanisms are rather complex, operating through various channels and involving the behaviour of all sectors of the economy (see below). 
This study makes a contribution to the existing literature in a number of ways. Several common institutional features of EMEs_-discusssed below—have led observers to argue that the traditional interest rate channel does not operate effectively in these economies. Thus, in the rest of the paper we focus on this channel of the monetary policy transmission mechanism and empirically test this argument by estimating structural equations for private consumption and private investment. This is in contrast with much of the existing literature on the monetary policy transmission mechanism in EMEs, which estimate VARs and look at overall output (GDP) instead of (potentially interest-sensitive) components of aggregate demand. Our study compares the interest rate elasticities of private consumption and investment demand in inflation targeting EMEs, prior to their adoption of IT, with five potential inflation targeters in the MENA region. Our study also compares the interest rate sensitivities of private consumption and private investment pre-IT and post-IT for the former group of countries. Finally, we examine how the interest rate sensitivities of private consumption and private investment vary with the level of development of the domestic financial market. To the best of our knowledge this has not been done in the existing literature to date.

Our study leads to four main findings. First, we find that the real lending rates do have a significant impact on private investment in both IT EMEs and MENA countries. Real deposit rates have a significant direct impact on private consumption in IT EMEs but not in MENA countries. Second, the adoption of IT did not significantly alter the operation of the traditional Keynesian interest rate channel of the monetary policy transmission process in IT EMEs. Third, the interest rate elasticities of private consumption and private investment vary with the level of development of the domestic financial sector. Whereas, for the IT EMEs, the wealth effect of changes in the real deposit rate increasingly dominates the substitution effect as the financial sector develops, the exact opposite is the case for the MENA EMEs. Also, development of the financial sector has no significant impact on private investment in the IT EMEs, either directly or indirectly through the interest rate channel, whereas our empirical findings suggest a significant impact (both direct and indirect) in the MENA EMEs. Fourth, liberalization of the capital account has widely different effects on private sector demand in our two groups of countries. In the IT EMEs, opening of the capital account has a positive impact on private investment but a negative impact on private consumption. On the other hand, for the MENA EMEs, opening of the capital account has a positive impact on private consumption, but a negative impact on private investment.

The paper proceeds as follows. Section II discusses in some detail the various channels through which monetary policy can affect aggregate demand and output. ${ }^{1}$ Section III presents a brief review of existing literature on the interest rate channel of the monetary policy transmission mechanism, more specifically on the effect of interest rates on private

\footnotetext{
${ }^{1}$ See Mishra et al. (2010) for a more exhaustive discussion of monetary policy transmission channels.
} 
consumption and private investment in the emerging market and MENA economies. Section IV discusses the data and methodology used in our empirical work. Section V presents and discusses the empirical results, and Section VI concludes with some thoughts on their policy implications.

\section{Channels Through Which Monetary Policy Can Affect Aggregate DEMAND}

Monetary policy affects aggregate demand through various channels. Four have been highlighted in the literature - the traditional interest rate channel; the credit or loan supply channel; the exchange rate channel; and the asset price channel.

- $\quad$ Traditional interest rate channel. This derives from standard Keynesian theory. The basic assumption is that prices are sticky and adjust to a monetary shock with a delay. Thus adjustments to the short-term nominal policy interest rate lead to changes in the short-term real interest rate. Moreover, long-term interest rates are also affected to the extent that market participants see the long-term interest rate as being a function of the sequence of short-term interest rates that are expected to prevail over time. Movements in real interest rates in turn influence the decisions of economic agents. More specifically, changes in the cost of capital affect the investment decision of firms, while consumption is affected by both wealth and substitution effects arising from changes in deposit interest rates and yields on treasury bonds.

- $\quad$ Credit channel. Monetary policy works not only through its impact on the demand for loans but also through the supply of loans. The credit channel in turn can be split into two different channels: the bank lending channel and the balance sheet channel.

On the bank lending channel contractionary monetary policy, for example through higher reserve requirements or Central Bank purchases of commercial bank reserve assets, results in lower usable reserve assets at commercial banks. Tighter monetary policy usually also leads to lower deposits at commercial banks through its impact on economic activity. These factors lower the supply of bank loans available, especially to small firms, thereby adversely affecting investment activity.

Monetary policy also affects the balance sheet of firms and therefore the value of their assets that can serve as collateral. Higher interest rates reduce cash-flow and have a negative effect on the prices of financial assets, resulting in lower net worth of firms, and so leads to lower investment spending. Weaker balance sheets also attenuate moral hazard and adverse selection problems and lead to lower access to funds for borrowing firms.

- $\quad$ Exchange rate channel. In the case of a flexible exchange rate regime and an open capital account, the initial impact of an increase in the interest rate is to make deposits in domestic currency more attractive than those in foreign currencies, leading to an exchange rate appreciation. The precise impact is uncertain and will depend on expectations about domestic and foreign interest rates and inflation, which may 
themselves be affected by a policy change. At a second stage, the appreciation of the exchange rate will have a direct impact on the prices of tradables through imported goods and services, and will also affect net exports (and therefore GDP and economic activity) by altering the relative prices of exports and imports.

- $\quad$ Asset price channel. Another potential transmission channel of monetary policy is through fluctuations in assets prices. A tighter monetary policy can put downward pressure on equity prices, and on the prices of other financial assets and real estate, by making these assets relatively less attractive compared to bonds. Falling asset prices can affect aggregate demand in two ways. First, as long-term interest rates rise and the value of housing and financial assets such as stocks and bonds fall, this translates into lower financial wealth of households and thereby reduces household consumption. And second, lower prices of financial assets reduce the market value of firms relative to the replacement cost of capital (Tobin's q), adversely affecting investment demand.

EMEs have several common institutional features which differentiate them from advanced economies:

(i) their financial systems are generally underdeveloped and dominated by banks, with a large share of households and small- and medium-sized enterprises lacking access to financial services;

(ii) their judicial systems are also weak, in that property rights can be difficult to enforce, which reduces considerably the investment opportunities for banks;

(iii) banks in these economies tend to operate in an oligopolistic environment, which limits even further the responsiveness of the lending rate to monetary shocks;

(iv) their interbank markets are usually very thin;

(v) bank loans and T-bills are highly imperfect substitutes in these economies due to the thinness of financial markets and lack of competition among banks; and

(vi) shocks to money supply occur mostly through the external channel in many EMEs, with shocks due to the volatility of aid, remittances, and export revenues in particular playing an important role.

These common features have important implications for the effectiveness of monetary policy. Given the underdevelopment of their financial systems one would not expect the interest rate channel to play a prominent role in the transmission of monetary policy in EMEs. The same is true for the bank lending and the asset price channels. We go on to test if it is indeed the case that the interest rate channel is weak in EMEs. We do this by estimating structural equations for private consumption and private investment in IT EMEs and in EMEs in the MENA region that may adopt IT in the foreseeable future. We pay particular attention to the interest rate elasticities of private consumption and private investment in these economies, examining whether they vary with the level of financial development. We also examine 
whether the adoption of IT had any significant impact on these interest elasticities in the inflation targeting EMEs in our sample.

\section{LITERATURE REVIEW}

Empirical research on the interest rate channel operating through the cost of capital have provided conflicting results, particularly with regard to the MENA region. Most existing empirical studies are country-based and use a standard Vector Auto Regression (VAR) methodology, and as a result the literature lacks a panel data-based approach and gives conflicting results on the transmission channels of monetary policy in emerging market economies. Neaime (2008) for example concludes that the traditional Keynesian interest rate channel dominates the transmission mechanism of monetary policy in Morocco and Tunisia, and that the direct linkages between the interest rate and inflation rates are highly significant. Boughrara (2009) finds that the credit channel is stronger than the traditional interest rate channel in Tunisia, and that neither the exchange rate channel nor the asset price channel are operative in either Tunisia or Morocco. By contrast Jardak and Wrobel (2009) conclude that the exchange rate channel is the most important in the Tunisian economy. Mishra et al. (2010) argue that for low income countries the strength and reliability of the monetary transmission mechanism depend critically on the effectiveness of the bank lending channel in the presence of limited financial development. Also, they argue that the bank lending channel will operate quite differently in low income countries from what we observe in industrial and emerging economies because of the limited degree of financial development in many low income countries. They primarily compare the correlation between changes in money market rate and lending rates in advanced, emerging and low income countries, and find the correlation coefficient to be weaker for the low income countries relative to advanced and emerging market economies. They explain the weaker coefficient in low income countries in terms of the institutional deficiencies that discourage bank lending activity.

There is a large body of empirical literature on the impact of interest rates on private consumption in advanced economies, but there are relatively few cross-country studies for emerging market and MENA economies. ${ }^{2}$ Fry (1978) estimates a (national) savings function for seven Asian countries for the period 1962-72 and finds strong support for the hypothesis of a negative and statistically significant real interest rate elasticity of domestic consumption. He estimates this elasticity to be about -0.2. Similar conclusions are reached by McDonald (1983). McDonald focuses on factors determining savings behavior in 12 Latin American countries and finds evidence of a statistically significant negative relationship between the real interest rate and private consumption in most of the countries examined, with estimated elasticities roughly comparable with that found by Fry (1978). Giovannini (1983) uses the same specification and the same set of countries as Fry (1978) but extends the analysis

${ }^{2}$ For empirical studies on advanced economies see Campbell and Mankiw (1989), Gruber (2006), Elmendorf (1996), Sarno and Taylor (1998). 
through the late 1970s. However, he does not find any significant relationship between consumption and the real interest rate. Rossi (1988) argues that in low-income developing countries that are characterized by pervasive liquidity constraints, consumption growth is more likely to follow income growth than changes in expected rates of return. Reinhart and Ostry (1995) describe that for a large number of developing countries, there does not appear to be any systematic relationship between rates of return and private consumption behavior due to the poor quality of data in general and the fact that there is considerable variation in the economic significance and informational content of available data on real rates of return. They also argue that the lack of sophistication and depth in financial markets or direct regulation may result in interest rates that do not adequately reflect expectations about underlying economic fundamentals. Using a panel of 16 emerging markets Funke (2002) finds a small but statistically significant effect of stock market developments on private consumption. ${ }^{3}$ However, to the best of our knowledge, there is no comprehensive study on the interest rate sensitivity of private consumption in emerging market or MENA economies, nor any empirical studies investigating the impact of financial development and capital market openness on private consumption. ${ }^{4}$

More empirical work has been done to assess the impact of the real interest rate on private investment in emerging market economies. Sundararajan and Thakur (1980), TunWai and Wong (1982), and Blejer and Khan (1984) address the analytical and data problems involved in its application to developing countries, in particular the lack of data and the resource constraints facing private investors in developing countries. Regarding the determinants of private investment, the neoclassical model suggests that a rise in the real interest rate raises the cost of borrowing, thereby reducing the private investment. Further, a flexible accelerator model of investment suggests that private investment should be positively related to expected future real GDP growth. Greene and Villanueva (1991) estimate the investment function for 23 developing economies from 1975-87 and find that the real interest has a significantly negative effect on private investment. They find that a one percentage point rise in the real interest rate reduces the private investment by 0.1 percentage point. Serven (2003) also finds that private investment in less developed countries responds significantly to interest rate changes. ${ }^{5}$ Using a panel data approach, Aysan et al. (2005) find that the real interest rate had a negative impact on firms' investment projects in five MENA countries (Egypt, Iran, Jordan, Morocco and Tunisia) throughout the 1980s and 1990s, while Bader and Malawi (2010) provide evidence of a significant negative impact of the real interest rate on private investment in Jordan between 1990 and 2005. Turning to Africa, Misati and Nyamongo

\footnotetext{
${ }^{3}$ The 16 EMEs in the study include Argentina, Brazil, Chile, Colombia, India, Indonesia, Korea, Malaysia, Mexico, Nigeria, Pakistan, Philippines, Thailand, Turkey, Venezuela and Zimbabwe.

${ }^{4}$ Except for some country specific studies, for example Townsend and Ueda (2010) on Thailand, Reinhart et al. (2003) on sub-Saharan African countries.

${ }^{5}$ For 61 less developed countries from 1975-1995.
} 
(2010) also find a significant and negative relationship between the interest rate on deposits and private investment for 18 African countries over the period 1991-2004. However, they do not find any impact of stock market turnover on private investment. Misati (2007) examines the effect of stock market development on investment efficiency in Africa and finds that stock market development matters for investment efficiency in countries in Africa with relatively developed stock markets; however, no consistent results are obtained for countries with relatively underdeveloped stock markets. The study concludes that African stock markets can boost investment efficiency by enhancing privatization and diversifying financial instruments.

Several studies have argued that capital account openness is an important determinant of investment decisions in emerging market economies. With closed capital markets investment only takes place up to the point where domestic savings equal domestic investment at a given rate of interest. With liberalization of capital account, resources should flow-at least in theory - from capital-abundant developed countries (where the return to capital is low) to capital-scarce developing countries (where the return to capital is high). The flow of resources to developing and emerging market economies reduces their cost of capital, triggering a temporary increase in investment (Fischer (1998, 2003), Obstfeld (1998), Rogoff (1999), Summers (2000).

Existing empirical studies find contradictory results on the effect of financial liberalization on private investment in low income and emerging market economies. Henry (2000a) examines the relationship between stock market liberalization and the growth of real private investment using an event study approach in 11 low income and emerging market economies. ${ }^{6}$ His study suggests that, on average, these economies experienced a large but temporary increase in the growth rate of real private investment on the heels of stock market liberalization. Henry (2000b) also argues that stock market liberalization decreases the cost of equity capital and thereby boosts private investment. Achy (2003) finds a significant negative impact of financial liberalization on private investment for five MENA countries over the period 1970-1998. ${ }^{7}$ He argues that, by distorting private credit allocation in favor of households at the expense of firms, financial liberalization has tended to reduce available loans for the business sector, and in particular for small and medium-sized enterprises. Naceur et al (2008) by contrast fail to find any significant impact of stock market liberalization on investment growth using annual data for 11 MENA countries over the period 1979-2005. ${ }^{8}$

\footnotetext{
${ }^{6}$ Argentina, Brazil, Chile, Colombia, India, Korea, Malaysia, Philippines, Thailand and Venezuela.

${ }^{7}$ Egypt, Jordan, Morocco, Tunisia and Turkey.

${ }^{8} 11$ MENA countries: Bahrain, Egypt, Iran, Jordan, Lebanon, Kuwait, Morocco, Oman, Saudi Arabia, Tunisia and Turkey.
} 


\section{Data AND Methodology}

We now go on to estimate augmented versions of standard consumption and investment equations found in the existing theoretical literature. Our consumption function is motivated by the life-cycle theory of consumption, which predicts that consumption is a function both of current real income and the expected lifetime income of the consumer, with the relationship between the two varying with age across the life cycle of the consumer. Our investment function is an extension of the accelerator model of investment, in which current investment is a function of anticipated output growth.

More specifically, we examine the interest rate elasticities of private consumption and private investment by estimating the following functions:

Consumption function:

$$
\begin{aligned}
\ln \left(\frac{C_{i, t}}{Y_{i, t}}\right)= & \propto_{0}+\propto_{r} \ln r_{i, t}^{D}+\propto_{r I T} \ln r_{i, t}^{D} * D_{I T}+\propto_{I T} D_{I T}+\propto_{r f d} \ln r_{i, t}^{D} * f d_{i, t}+ \\
& \propto_{f d} f d_{i, t}+\propto_{k o} k o_{i, t}+\propto_{G / Y} \ln \left(\frac{G_{i, t}}{Y_{i, t}}\right)+\propto_{y} \ln y_{i, t}+ \\
& \propto_{\text {pop }}\left(\frac{P o p}{\text { Tot_pop }}\right)_{i, t}+\varepsilon_{i, t}
\end{aligned}
$$

where the subscripts $i$ represents country and $t$ represents time.

$C$ is the private consumption at constant prices, $Y$ is the GDP at constant prices, $r^{D}$ is the real deposit rate, $G$ is the government consumption at constant prices, $y$ is the real GDP per capita, Pop is population aged 14 and less and 65 and more, Tot_pop is total population, $k o$ is the Chinn-Ito index of capital openness, $f d$ is a financial market development index and $\varepsilon$ is the disturbance term. The Chinn-Ito capital openness index (Chinn and Ito (2008)) ranges from (-1.83) to 2.50, where higher values indicate a more financially open economy. The financial development index is a sum of stock market capitalization and credit to the private sector, both measured as shares of GDP. $D_{I T}$ is an inflation targeting dummy that is equal to one if the country is targeting inflation and zero otherwise. In theory an increase in real interest rates, given wealth, has two opposing effects. The first it to make consumption later more attractive as the return on savings increases: this is the substitution effect. The second is to allow for higher consumption both now and in the future: this is the wealth effect. In general, the net effect on the marginal propensity to consume is ambiguous.

Investment function:

$$
\begin{aligned}
\ln \left(\frac{I_{i, t}}{Y_{i, t}}\right)= & \beta_{0}+\beta_{r} \ln r_{i, t}^{L}+\beta_{r I T} \ln r^{L}{ }_{i, t} * D_{I T}+\beta_{I T} D_{I T}+\beta_{r f d} \ln r_{i, t}^{L} * f d_{i, t}+ \\
& \beta_{f d} f d_{i, t}+\beta_{k o} k o_{i, t}+\beta_{g y} \ln (g y)_{i, t+1}+\epsilon_{i, t}
\end{aligned}
$$


Where, as in the consumption equation, the subscripts $i$ represents country and $t$ represents time. $I$ is the private investment at constant prices, $Y$ is the GDP at constant prices, $r^{L}$ is the real lending rate, $g y$ is expected output growth over the coming year, $\epsilon$ is the disturbance term, and $k o, f d$ and $D_{I T}$ are as defined before in the consumption equation.

We estimate separate equations for two groups of countries. The first group consists of 14 EMEs which have adopted IT, and the second group consists of five EMEs in the MENA region that may adopt IT in the foreseeable future. ${ }^{9}$ We use annual data covering the period 1990 to 2009. Table 1 presents the list of countries included in the empirical analysis, while Tables 2 and 3 provide details of the data sources and the summary statistics for each of the variables used in our study.

Our estimated equations include standard variables from the existing literature. The dependent variables, private consumption and private investment, are scaled by GDP, in line with the existing literature (for example, Fry (1978), Giovannini (1983), Greene and Villanueva (1991), Serven (2003). The real deposit and real lending rates are constructed by subtracting one-year ahead forecasts of the consumer price inflation rate from the IMF's World Economic Outlook (WEO) publications from nominal deposit and nominal lending rates respectively. The coefficients on the real deposit rate and on the real lending rate represent the direct interest rate elasticities of private consumption and private investment respectively. In our private consumption equation, we also control for government consumption scaled by GDP, real per capita GDP, and the age dependency ratio. In line with the accelerator model of investment we include expected output growth as an explanatory variable in the private investment equation. Specifically, one-year ahead GDP growth forecasts from the WEO have been used as a proxy for expected output growth in the investment equation. To the best of our knowledge this is the first empirical study to use WEO one-year ahead forecasts as a proxy for expected inflation and expected output growth. ${ }^{10}$

\footnotetext{
${ }^{9}$ Excluding the so-called 'economies of transition' (the Czech Republic, Hungary, Poland and Romania) from the IT EMEs and re-estimating the equations did not have any significant impact on the empirical results.

${ }^{10}$ Following some empirical studies we also controlled for remittances from abroad in our estimated equations. However, we did not find any significant impact of remittances on either private consumption or investment for either IT EMEs or for the potential inflation targeters in the MENA region. Consequently, in the estimated equations reported in this paper we have dropped remittances as an explanatory variable.
} 


\section{Table 1. Countries Included in our Empirical Study}

\section{Inflation targeting EMEs (Year of adoption of inflation targeting)}

1. Brazil (1999)

2. Chile (1999)

3. Colombia (1999)

4. Czech Republic (1997)

5. Hungary (2001)

6. Indonesia (2005)

7. Mexico (2001)

8. $\quad$ Peru (2002)

9. Philippines (2002)

10. Poland (1998)

11. Romania (2005)

12. South Africa (2000)

13. Thailand (2000)

14. Turkey (2006)

\section{MENA EMEs}

\section{Egypt}

2. Jordan

3. Lebanon

4. Morocco

5. Tunisia

Source: IMF staff. 
Table 2. Data Sources of the Variables Used in our Empirical Study

\begin{tabular}{|c|c|c|}
\hline Variables & Measured as & Data (Source) \\
\hline $\begin{array}{l}\text { In(Real private } \\
\text { consumption/Real GDP) }\end{array}$ & $\begin{array}{l}\text { In(Private consumption, } \\
\text { constant prices/GDP, constant } \\
\text { prices) }\end{array}$ & WEO \\
\hline $\begin{array}{l}\text { In(Real private investment/Real } \\
\text { GDP) }\end{array}$ & $\begin{array}{l}\text { In(Private investment, constant } \\
\text { prices/GDP, constant prices) }\end{array}$ & WEO \\
\hline In(Real deposit rate) & $\begin{array}{l}\text { In(1+(Nominal deposit rate - } \\
\text { WEO forecast of one period } \\
\text { ahead CPI inflation }))\end{array}$ & Nominal deposit rate: IFS \\
\hline In(Real lending rate) & $\begin{array}{l}\text { In(1+(Nominal lending rate - } \\
\text { WEO forecast of one period } \\
\text { ahead CPI inflation) })\end{array}$ & Nominal lending rate: IFS \\
\hline $\begin{array}{l}\text { In(Real government } \\
\text { consumption/Real GDP) }\end{array}$ & $\begin{array}{l}\text { In(Government consumption, } \\
\text { constant prices/GDP, constant } \\
\text { prices) }\end{array}$ & WEO \\
\hline In(Real GDP per capita) & In(Real GDP per capita) & WEO \\
\hline Financial development index & $\begin{array}{l}\text { (Stock market } \\
\text { capitalization/GDP) + (Private } \\
\text { credit by deposit money } \\
\text { banks/GDP) }\end{array}$ & $\begin{array}{l}\text { World Bank data on Financial } \\
\text { Development and Structure }^{11}\end{array}$ \\
\hline $\begin{array}{l}\text { (Pop aged }<=14,>=65 \text { ) / total } \\
\text { population }\end{array}$ & $\begin{array}{l}((\text { Pop aged }<=14,>=65) / \text { total } \\
\text { population })^{\star} 100\end{array}$ & WDI \\
\hline Dummy for IT & $\begin{array}{l}D_{I T}=1 \text { if the country is } \\
\text { targeting inflation, and } D_{I T}=0 \\
\text { otherwise }\end{array}$ & $\begin{array}{l}\text { Date of adoption of inflation } \\
\text { targeting collected from central } \\
\text { banks' website }\end{array}$ \\
\hline Capital openness & & $\begin{array}{l}\text { Chinn-Ito index of capital } \\
\text { openness }\end{array}$ \\
\hline WEO GDP growth forecast & $\begin{array}{l}\text { WEO forecast of one year } \\
\text { ahead GDP growth }\end{array}$ & WEO \\
\hline
\end{tabular}

Source: IMF staff.

\footnotetext{
${ }^{11}$ Beck, Demirgüç-Kunt and Levine (2000).
} 
Table 3. Summary Statistics of the Variables Used in our Empirical Study

\begin{tabular}{|c|c|c|c|c|}
\hline Variable & Mean & $\begin{array}{l}\text { Standard } \\
\text { Deviation }\end{array}$ & Min. & Max. \\
\hline $\begin{array}{l}\text { In(Real private } \\
\text { consumption/Real GDP) }\end{array}$ & -0.685 & 0.624 & -7.04 & 1.98 \\
\hline $\begin{array}{l}\text { In(Real private } \\
\text { investment/Real GDP) }\end{array}$ & -1.536 & 0.711 & -3.08 & -1.07 \\
\hline $\begin{array}{l}\text { In(Real deposit rate) } \\
(\text { as \%) }\end{array}$ & 4.512 & 1.039 & 4.17 & 9.15 \\
\hline $\begin{array}{l}\text { In(Real lending rate) } \\
\text { (as \%) }\end{array}$ & 4.229 & 1.495 & 4.30 & 8.44 \\
\hline $\begin{array}{l}\text { In(Real government } \\
\text { consumption/Real GDP) }\end{array}$ & -1.89 & .674 & -3.10 & 0.585 \\
\hline In(Real GDP per capita) & 10.54 & 3.06 & 6.84 & 16.05 \\
\hline $\begin{array}{l}\text { Financial development } \\
\text { index }\end{array}$ & 0.759 & 0.649 & 0.216 & 3.89 \\
\hline $\begin{array}{l}\text { (Pop aged }<=14,>=65) / \\
\text { total population }(\text { as } \%)\end{array}$ & 34.74 & 8.961 & 28.54 & 49.99 \\
\hline Dummy for IT & 0.45 & 0.49 & 0 & 1 \\
\hline Capital openness & 0.151 & 1.41 & -1.83 & 2.50 \\
\hline $\begin{array}{l}\text { WEO GDP growth forecast } \\
\text { (as \%) }\end{array}$ & 5.78 & 9.73 & -0.66 & 91.73 \\
\hline
\end{tabular}

Source: IMF staff calculations.

However, additional explanatory variables, not commonly used in the existing literature, are included to examine in more detail the interest responsiveness of private consumption and private investment. Specifically, various interactive dummies are included in the estimated equations to see if the interest rate elasticities of private consumption and private investment vary with the level of development of the domestic financial market. We also examine whether the level of financial development and the openness of the capital account affect 
private consumption and investment through channels other than the interest rate. Furthermore, for inflation targeting EMEs we include a time dummy to see if these elasticities have changed significantly following their adoption of inflation targeting.

Before estimating the equations we test for stationarity of the variables. For this we use Augmented Dickey Fuller (ADF) tests with a trend term and a lag term, where the optimal lag length for each variable was selected using the Schwarz Criterion (SC). The null hypothesis $\left(H_{0}\right)$ for the stationarity tests is that the variable is non-stationary (has a unit root), and the alternative hypothesis $\left(H_{A}\right)$ suggests that the variable is stationary (with no unit root). The ADF test results are summarized in Table 4 below and reject the null hypothesis of a unit root for all of the variables, suggesting that they are all stationary.

Table 4. Stationarity Test Results

Variable

Real private consumption/Real GDP

Real private investment/Real GDP

Real deposit rate

Real lending rate

Real government consumption/Real GDP

Real GDP per capita

Financial development index

(Pop aged <=14, >= 65) / total population

Dummy for IT

Capital openness

WEO GDP growth forecast
ADF test statistic (\# of lag selected by SC)

$-3.089^{\star \star}(1)$

$-3.918^{\star \star \star}(1)$

$-3.143^{\star \star}(1)$

$-3.821^{\star \star \star}(1)$

$-3.223^{\star \star}(1)$

$-2.673^{*}(5)$

$-4.985^{\star \star \star}(1)$

$-5.415^{\star \star \star}(3)$

$-5.086^{\star \star \star}(1)$

$-4.207^{\star \star *}(1)$

$-5.924^{\star \star \star}(6)$

Source: IMF staff estimates.

(** Significant at $1 \%$ level, ${ }^{* *}$ Significant at $5 \%$ level, * Significant at $10 \%$ level.) 
There are several challenges with the estimation of equations (1) and (2). First, the equations suffer from the endogeneity problem in that some of the explanatory variables, for example real GDP per capita and expected output growth, can be said to be affected by the dependent variable(s). Second, the Breusch-Pagan test for heteroskedasticity ${ }^{12}$ suggests that the error terms from all our estimated consumption and investment equations are heteroskedastic. To overcome these problems, and since we do not have a lagged dependent variable in our equations, we favor using IV-GMM (General Method of Moments with lagged endogenous variables as instruments), as discussed in more detail below.

\section{EMPIRICAL RESULTS}

In this section, we present the results from estimating our private consumption and investment equations using pooled ordinary least squares (OLS), fixed effects IV and IVGMM. Coefficient estimates from pooled OLS suffer from endogeneity bias, which can be addressed by using instrumental variables. However, in the presence of heteroskedastic error terms, fixed effects IV give biased estimates. ${ }^{13}$ Therefore, we favor the IV-GMM methodology since this gives us coefficient estimates that are corrected for endogeneity, heteroskedasticity and autocorrelation. ${ }^{14}$ To examine the validity of our instruments we apply Hansen's J test, where the null hypothesis is that the instruments as a group are exogenous. The p-values of the Hansen J statistics fail to reject the null hypothesis, implying that our instrument set is valid.

Table 5 and Table 6 present our estimates of private consumption functions in IT EMEs and MENA EMEs respectively. The coefficient on government consumption is significantly negative for IT EMEs, suggesting that private consumption and government consumption are substitutes in the household utility function. However, the coefficient is significantly positive for the MENA countries, indicating that government consumption and private consumption are complements in the household utility function in these countries. This could reflect differences in the role of government in our two groups of countries, with government consumption playing more of a social safety net role in MENA countries compared with the IT EMEs in our sample. ${ }^{15}$ Real GDP per capita does not have a significant impact on private

\footnotetext{
${ }^{12}$ Breusch-Pagan test statistic, a Lagrange multiplier measure, is distributed Chi-squared(p) under the null hypothesis of homoskedasticity. For IT consumption function, the Breusch-Pagan LM statistic: 92.92018 Chi-sq P-value $=1.4 \mathrm{e}-15$; For IT investment function, the Breusch-Pagan LM statistic: 22.09768 Chi-sq P-value = 0.0047; For Non-IT MENA consumption function, the Breusch-Pagan LM statistic: 27.70852 Chi-sq P-value = .0016; For Non-IT MENA investment function, the Breusch-Pagan LM statistic: 24.12635 Chi-sq P-value = 0.0011. These test statistics suggest that in all above cases we reject the null hypothesis of homoskedasticity.

${ }^{13}$ Fixed effects assume that the error terms are homoskedastic.

${ }^{14}$ Since we are using lagged endogenous variables as instruments, the coefficient estimates corrected for autocorrelation are more efficient.

${ }^{15}$ For example, IMF staff estimates indicate that general government spending on goods and services averaged less than 7 percent of public consumption expenditures in Jordan, Lebanon and Tunisia over the period
} 
consumption in the IT EMEs; however, it has a significantly positive impact on private consumption in the MENA countries. One possible explanation could be that greater openness of the capital account in IT EMEs provides greater opportunities for consumptionsmoothing relative to many of the MENA countries in our sample (see below); thus consumers in the IT EMEs may be less constrained by current levels of real income. Moreover, for the IT EMEs, we find that neither the coefficient on the IT dummy, nor the coefficient on the interactive term with the real deposit rate and the IT dummy are significant. This implies that the adoption of inflation targeting did not have a significant impact on private consumption behavior in these economies.

The responsiveness of private consumption to movements in the deposit interest rate is very different across our two groups of countries. The interest rate elasticity of consumption is significantly negative for the IT EMEs, but is not significantly different from zero for the MENA EMEs. Moreover, for the IT EMEs our empirical results suggest that the level of financial development has a statistically significant negative direct effect on private consumption, and that the interest rate elasticity of private consumption decreases (becomes less negative) with the level of development of the domestic financial sector. In short, as the level of financial development increases, the wealth effect of changes in the real deposit rate increasingly dominates the substitution effect. For the MENA EMEs we get the opposite results: the level of financial development has a statistically significant positive direct effect on private consumption, while the interest rate elasticity of private consumption increases (becomes more negative) with the level of development of the domestic financial sector. That is, the substitution effect of changes in the real deposit rate becomes increasingly important as the financial sector develops.

Our contrasting results for the two groups of countries can be explained in part by differences in the levels of development of the domestic financial sector. Figure 1 plots the interest rate elasticity of private consumption against the financial development index for the IT EMEs. It shows that, at low levels of financial development, the negative substitution effect of movements in the real deposit rate dominates the positive wealth effect, resulting in a negative interest rate elasticity of private consumption. However, as the financial development index rises above $3.36,{ }^{16}$ the wealth effect starts to dominate the substitution effect and the interest rate elasticity becomes positive. In short, it is only at relatively advanced stages of financial development that the wealth effect starts to dominate the

2000-2009. By contrast, for the IT EMEs in our sample for which data is available, the ratio varied from 12 percent in Indonesia to 65 percent in Brazil. Although fully comparable disaggregated data on government spending is not available, the implication is that government spending on subsidies and transfers, social benefits and compensation of employees are significantly higher as a share of total government consumption in the MENA region compared to the IT EMEs in our study.

${ }^{16}$ Here financial development index is measured as a sum of stock market capitalization and credit to the private sector, both measured as shares of GDP. 
substitution effect. It is noteworthy that the maximum value of the financial development index in the MENA EMEs is 3.25, which is below the value of 3.36 at which the positive wealth effect kicks in for the IT EMEs. Thus, one reason why we cannot identify a positive wealth effect on private consumption from movements in the real deposit rate in the MENA EMEs is the relatively low level of development of the domestic financial sector.

Table 7 and Table 8 present the coefficients from our estimated private investment equations for IT EMEs and MENA EMEs respectively and provide interesting insights on the interest rate elasticity of private investment. Our estimates show that the real lending rate has a statistically significant and negative impact on private investment in both IT EMEs and non-IT MENA EMEs. Also, expected output growth over the coming year has a significantly positive effect on private investment for both groups of countries, consistent with the accelerator model of investment. As with private consumption, for the IT EMEs adoption of IT did not have a significant effect either on private investment or on the interest rate elasticity of private investment. Furthermore, for the IT EMEs greater openness of the capital account boosts private investment directly. However, the level of development of the domestic financial sector has no significant impact on private investment, either on its own or through the interest rate channel. Once again, for the non-IT MENA EMEs we get the opposite results: the coefficient on the capital openness index variable is statistically significant and negative, while financial development has a positive direct effect on private investment, and the interest rate elasticity of private investment increases (becomes more negative) with the level of development of the domestic financial sector.

Our regression results suggest that development of the domestic financial market and liberalization of the capital account have widely differing effects on private sector demand in our two groups of countries. For the IT EMEs, opening of the capital account has a positive impact on private investment but a negative impact on private consumption. Development of the domestic financial market has no significant impact on investment, direct or indirect, but has a significant direct negative impact on private consumption. However, for the MENA EMEs, as capital account openness increases, private consumption rises but private investment declines. As for the domestic financial market, its development has a positive and significant direct impact on both private consumption and investment. Possible explanations for these contrasting results are that the MENA EMEs are, in general, poorer and provide an unfriendly business environment and inadequate institutional support for investment compared with the IT EMEs (see Nabli (2007) and Makdisi et al. (2007)). Thus greater opportunities for borrowing and lending, through development of domestic financial markets or opening of the capital account, tends to promote private consumption rather than private investment in the MENA EMEs, while the opposite appears to be the case for the IT EMEs, possibly due to higher living standards and more conducive business environments. 
Table 5. Consumption Function for IT-EMEs

(Dependent Variable: In (Real private consumption/Real GDP)

\begin{tabular}{|c|c|c|c|c|}
\hline Variable & Coefficient & $\begin{array}{l}\text { Pooled } \\
\text { OLS }\end{array}$ & $\begin{array}{l}\text { Fixed } \\
\text { effects IV }\end{array}$ & IV-GMM \\
\hline In(Real deposit rate) & $\propto_{d}$ & $\begin{array}{l}-0.167^{\star * *} \\
(0.030)\end{array}$ & $\begin{array}{l}0.012 \\
(0.84)\end{array}$ & $\begin{array}{l}-0.258^{\star * *} \\
(0.044)\end{array}$ \\
\hline Dummy for IT & $\propto_{I T}$ & $\begin{array}{l}1.99^{*} \\
(1.05)\end{array}$ & $\begin{array}{l}-0.353 \\
(0.686)\end{array}$ & $\begin{array}{l}1.87 \\
(1.70)\end{array}$ \\
\hline In(Real deposit rate)* IT Dummy & $\propto_{d I T}$ & $\begin{array}{l}-0.422^{*} \\
(0.226)\end{array}$ & $\begin{array}{l}0.074 \\
(0.147)\end{array}$ & $\begin{array}{l}-0.391 \\
(0.366)\end{array}$ \\
\hline Financial development index & $\propto_{f d}$ & $\begin{array}{l}-0.900^{\star \star *} \\
(0.243)\end{array}$ & $\begin{array}{l}0.933 \\
(1.13)\end{array}$ & $\begin{array}{l}-1.54^{\star \star \star} \\
(0.362)\end{array}$ \\
\hline $\begin{array}{l}\text { In(Real deposit rate })^{\star} \text { Financial } \\
\text { development }\end{array}$ & $\propto_{d f d}$ & $\begin{array}{l}0.180^{\star \star *} \\
(0.052)\end{array}$ & $\begin{array}{l}-0.198 \\
(0.243)\end{array}$ & $\begin{array}{l}0.077^{\star \star *} \\
(0.168)\end{array}$ \\
\hline Capital account openness & $\propto_{k o}$ & $\begin{array}{l}-0.019^{\star \star \star} \\
(0.006)\end{array}$ & $\begin{array}{l}-0.004 \\
(0.003)\end{array}$ & $\begin{array}{l}-0.022^{\star \star} \\
(0.010)\end{array}$ \\
\hline $\begin{array}{l}\text { In(Real government consumption/Real } \\
\text { GDP) }\end{array}$ & $\propto_{G / Y}$ & $\begin{array}{l}-0.120^{\star \star \star} \\
(0.026)\end{array}$ & $\begin{array}{l}-0.326^{\star \star \star} \\
(0.036)\end{array}$ & $\begin{array}{l}-0.142^{\star \star \star} \\
(0.047)\end{array}$ \\
\hline In(Real GDP per capita) & $\propto_{y}$ & $\begin{array}{l}-0.014^{\star \star \star} \\
(0.003)\end{array}$ & $\begin{array}{l}-0.224^{\star \star *} \\
(0.052)\end{array}$ & $\begin{array}{l}-0.006 \\
(0.005)\end{array}$ \\
\hline $\begin{array}{l}\text { (Pop aged }<=14,>=65 \text { ) / Total } \\
\text { population }\end{array}$ & $\propto_{p o p}$ & $\begin{array}{l}0.008^{\star * *} \\
(0.002)\end{array}$ & $\begin{array}{l}0.016^{* * *} \\
(0.004)\end{array}$ & $\begin{array}{l}0.015^{\star * *} \\
(0.004)\end{array}$ \\
\hline Number of observations & & 242 & 212 & 213 \\
\hline$R^{2}$ & & 0.95 & 0.28 & 0.95 \\
\hline $\mathrm{X}^{2} p$-value for Hansen $\mathrm{J}$ Statistic & & & 0.14 & 0.64 \\
\hline
\end{tabular}

Source: IMF staff estimates.

(Standard errors of coefficients in parenthesis. ${ }^{* *}$ Significant at $1 \%$ level, ** Significant at $5 \%$ level, * Significant at $10 \%$ level.) 


\section{Table 6. Consumption Function for Non-IT MENA EMEs}

(Dependent Variable: In (Real private consumption/Real GDP)

\begin{tabular}{|c|c|c|c|c|}
\hline Variable & Coefficient & Pooled OLS & Fixed effects IV & IV-GMM \\
\hline In(Real deposit rate) & $\propto_{d}$ & $\begin{array}{l}-0.184^{*} \\
(0.098)\end{array}$ & $\begin{array}{l}2.07 \\
(1.85)\end{array}$ & $\begin{array}{l}-0.188 \\
(0.203)\end{array}$ \\
\hline Financial development index & $\propto_{f d}$ & $\begin{array}{l}9.72^{\star \star \star} \\
(3.63)\end{array}$ & $\begin{array}{l}5.30 \\
(6.85)\end{array}$ & $\begin{array}{l}9.33^{\star *} \\
(3.86)\end{array}$ \\
\hline $\begin{array}{l}\text { In(Real deposit rate) })^{\star} \\
\text { Financial development }\end{array}$ & $\propto_{d f d}$ & $\begin{array}{l}-2.15^{\star \star \star} \\
(0.797)\end{array}$ & $\begin{array}{l}-1.13 \\
(1.48)\end{array}$ & $\begin{array}{l}-2.06^{\star \star} \\
(0.850)\end{array}$ \\
\hline Capital account openness & $\propto_{k o}$ & $\begin{array}{l}0.104^{\star * *} \\
(0.016)\end{array}$ & $\begin{array}{l}0.014^{*} \\
(0.007)\end{array}$ & $\begin{array}{l}0.102^{\star \star *} \\
(0.029)\end{array}$ \\
\hline $\begin{array}{l}\text { In(Real government } \\
\text { consumption/Real GDP) }\end{array}$ & $\propto_{G / Y}$ & $\begin{array}{l}0.677^{\star \star \star} \\
(0.066)\end{array}$ & $\begin{array}{l}-0.515 \\
(0.322)\end{array}$ & $\begin{array}{l}0.706^{\star \star \star} \\
(0.092)\end{array}$ \\
\hline In(Real GDP per capita) & $\propto_{y}$ & $\begin{array}{l}0.135^{\star \star \star} \\
(0.018)\end{array}$ & $\begin{array}{l}-0.396 \\
(0.326)\end{array}$ & $\begin{array}{l}0.134^{\star \star \star} \\
(0.036)\end{array}$ \\
\hline $\begin{array}{l}\text { (Pop aged }<=14,>=65) / \\
\text { Total population }\end{array}$ & $\propto_{p o p}$ & $\begin{array}{l}0.029^{* *} \\
(0.006)\end{array}$ & $\begin{array}{l}-0.017 \\
(0.015)\end{array}$ & $\begin{array}{l}0.023^{\star} \\
(0.013)\end{array}$ \\
\hline Number of observations & & 83 & 70 & 74 \\
\hline$R^{2}$ & & 0.94 & 0.34 & 0.95 \\
\hline $\begin{array}{l}\chi^{2} p \text {-value for Hansen } \mathrm{J} \\
\text { Statistic }\end{array}$ & & & 0.51 & 0.81 \\
\hline
\end{tabular}

Source: IMF staff estimates.

(Standard errors of coefficients in parenthesis. ${ }^{* \star}$ Significant at $1 \%$ level, ${ }^{*}$ Significant at $5 \%$ level * Significant at $10 \%$ level.) 
Table 7. Investment Function for IT-EMEs

(Dependent Variable: In (Real private investment/Real GDP)

\begin{tabular}{|c|c|c|c|c|}
\hline Variable & Coefficient & Pooled OLS & Fixed effects IV & IV-GMM \\
\hline In(Real lending rate) & $\beta_{l}$ & $\begin{array}{l}-0.007 \\
(0.072)\end{array}$ & $\begin{array}{l}-0.323 \\
(0.261)\end{array}$ & $\begin{array}{l}-0.464^{\star \star \star} \\
(0.030)\end{array}$ \\
\hline Dummy for IT & $\beta_{I T}$ & $\begin{array}{l}0.230 \\
(1.85)\end{array}$ & $\begin{array}{l}-0.776 \\
(2.44)\end{array}$ & $\begin{array}{l}-2.62 \\
(2.80)\end{array}$ \\
\hline $\begin{array}{l}\text { In(Real lending rate)* IT } \\
\text { Dummy }\end{array}$ & $\beta_{l I T}$ & $\begin{array}{l}-0.060 \\
(0.392)\end{array}$ & $\begin{array}{l}0.149 \\
(0.520)\end{array}$ & $\begin{array}{l}0.551 \\
(0.590)\end{array}$ \\
\hline Financial development index & $\beta_{f d}$ & $\begin{array}{l}1.75 \\
(2.10)\end{array}$ & $\begin{array}{l}1.64 \\
(2.26)\end{array}$ & $\begin{array}{l}2.98 \\
(3.11)\end{array}$ \\
\hline $\begin{array}{l}\text { In(Real lending rate)* } \\
\text { Financial development }\end{array}$ & $\beta_{l f d}$ & $\begin{array}{l}-0.357 \\
(0.450)\end{array}$ & $\begin{array}{l}-0.287 \\
(0.480)\end{array}$ & $\begin{array}{l}-0.627 \\
(0.662)\end{array}$ \\
\hline Capital account openness & $\beta_{k o}$ & $\begin{array}{l}0.091^{\star \star *} \\
(0.016)\end{array}$ & $\begin{array}{l}0.023 \\
(0.018)\end{array}$ & $\begin{array}{l}0.076^{\star \star *} \\
(0.027)\end{array}$ \\
\hline WEO GDP growth forecast & $\beta_{g y}$ & $\begin{array}{l}0.018^{\star \star} \\
(0.009)\end{array}$ & $\begin{array}{l}0.043^{*} \\
(0.024)\end{array}$ & $\begin{array}{l}0.078^{\star \star \star} \\
(0.024)\end{array}$ \\
\hline Number of observations & & 179 & 163 & 163 \\
\hline$R^{2}$ & & 0.22 & 0.30 & 0.98 \\
\hline $\begin{array}{l}\mathrm{X}^{2} p \text {-value for Hansen } \mathrm{J} \\
\text { Statistic }\end{array}$ & & & 0.25 & 0.65 \\
\hline
\end{tabular}

Source: IMF staff estimates.

(Standard errors of coefficients in parenthesis. ** Significant at $1 \%$ level, ** Significant at $5 \%$ level, * Significant at $10 \%$ level.) 
Table 8. Investment Function for Non-IT MENA-EMEs

Dependent Variable: In (Real private investment/Real GDP)

\begin{tabular}{|c|c|c|c|c|}
\hline Variable & Coefficient & Pooled OLS & Fixed effects IV & IV-GMM \\
\hline In(Real lending rate) & $\beta_{l}$ & $\begin{array}{l}-2.51^{\star \star} \\
(1.09)\end{array}$ & $\begin{array}{l}1.29 \\
(2.55)\end{array}$ & $\begin{array}{l}-0.561^{\star \star \star} \\
(0.056)\end{array}$ \\
\hline Financial development index & $\beta_{f d}$ & $\begin{array}{l}0.552^{\star \star \star} \\
(0.097)\end{array}$ & $\begin{array}{l}1.08^{\star *} \\
(0.564)\end{array}$ & $\begin{array}{l}0.693^{\star \star \star} \\
(0.157)\end{array}$ \\
\hline $\begin{array}{l}\text { In(Real lending rate) })^{\star} \\
\text { Financial development }\end{array}$ & $\beta_{l f d}$ & $\begin{array}{l}-0.132^{\star \star \star} \\
(0.019)\end{array}$ & $\begin{array}{l}-0.260^{*} \\
(0.139)\end{array}$ & $\begin{array}{l}-0.166^{\star \star \star} \\
(0.029)\end{array}$ \\
\hline Capital account openness & $\beta_{k o}$ & $\begin{array}{l}-0.096^{\star \star *} \\
(0.025)\end{array}$ & $\begin{array}{l}-0.048 \\
(0.032)\end{array}$ & $\begin{array}{l}-0.181^{* * \star} \\
(0.035)\end{array}$ \\
\hline WEO GDP growth forecast & $\beta_{g y}$ & $\begin{array}{l}0.080^{* * *} \\
(0.017)\end{array}$ & $\begin{array}{l}0.076^{* *} \\
(0.034)\end{array}$ & $\begin{array}{l}0.224^{\star * *} \\
(0.059)\end{array}$ \\
\hline Number of observations & & 81 & 72 & 72 \\
\hline$R^{2}$ & & 0.48 & 0.22 & 0.98 \\
\hline $\begin{array}{l}\mathrm{X}^{2} p \text {-value for Hansen } \mathrm{J} \\
\text { Statistic }\end{array}$ & & & 0.76 & 0.18 \\
\hline
\end{tabular}

Source: IMF staff estimates.

(Standard errors of coefficients in parenthesis. ${ }^{\star \star *}$ Significant at $1 \%$ level, ** Significant at $5 \%$ level, * Significant at $10 \%$ level.) 


\section{Figure 1. Interest Rate Elasticity of Private Consumption and Financial Development Index in Inflation Targeting Emerging Market Economies}

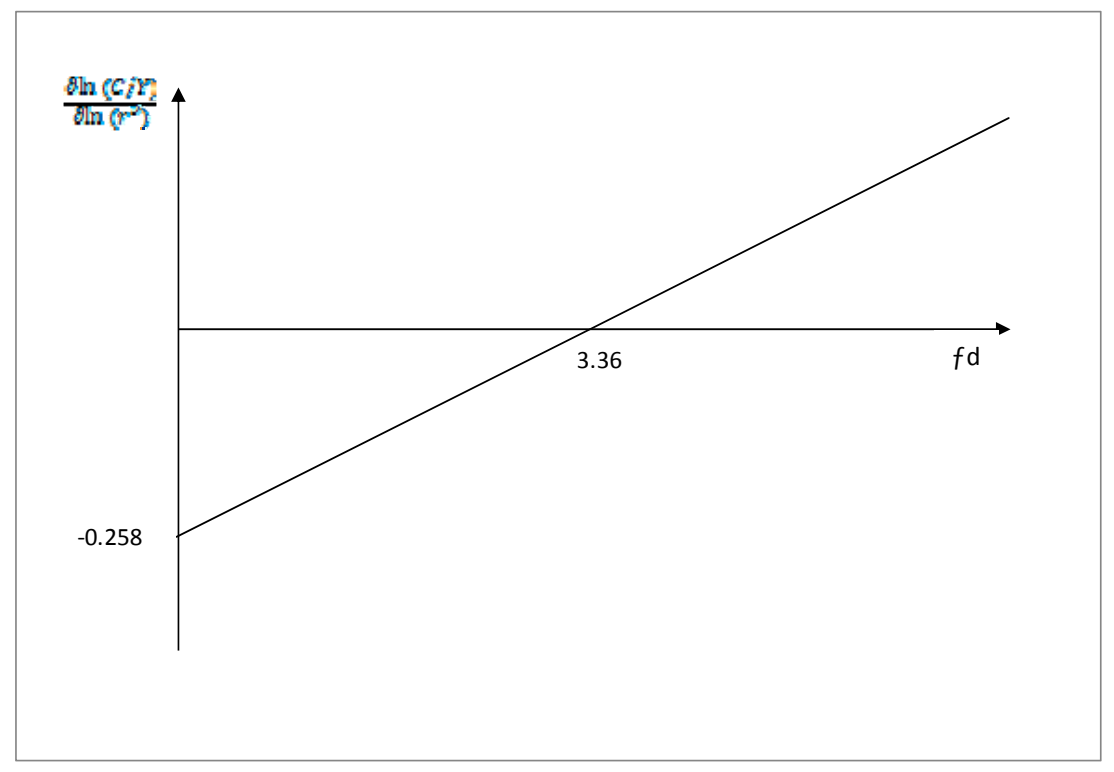

Source: IMF staff estimates.

\section{CONCLUSIONS}

Four broad conclusions that have policy relevance can be drawn from our empirical results:

First, contrary to what a review of the existing literature might indicate, our results suggest that interest rates do have a significant impact on private sector activity in both IT EMEs and in potential inflation targeters in the MENA region. Our estimates show that the real lending rate has a statistically significant and negative impact on private investment in both groups of countries. The real deposit interest rate also has an important impact on private consumption in IT EMEs, but for the potential inflation targeters in the MENA region the interest rate elasticity of private consumption varies directly with the level of financial development. In short, our empirical results provide no support for the argument that inflation targeting is unlikely to be successful in the MENA region because the traditional Keynesian interest rate channel is weak or does not operate effectively.

Second, adoption of inflation targeting did not significantly alter the operation of the traditional Keynesian interest rate channel of the monetary policy transmission process in emerging market economies. Our results show that, for the IT EMEs in our study, adoption of IT did not have a significant direct impact on private consumption or investment behavior, nor did it affect the responsiveness of private consumption and investment to movements in interest rates. 
Third, the interest rate elasticities of private consumption and private investment vary with the level of development of the domestic financial sector. For the IT EMEs, our empirical results suggest that financial sector development has a statistically significant negative direct effect on private consumption, and that the interest rate elasticity of private consumption decreases (becomes less negative) with the level of development of the domestic financial sector. In short, as the financial sector develops, the wealth effect of changes in the real deposit rate increasingly dominates the substitution effect. However, financial sector development has no significant impact on investment, either directly or indirectly through the interest rate channel. The results for the MENA EMEs by contrast suggest that development of the domestic financial sector has a statistically significant and positive direct effect on private investment, and that the interest rate elasticity of private investment increases (becomes more negative) with the level of development of the domestic financial sector. Also, financial sector development has a statistically significant positive direct effect on private consumption, while the interest rate elasticity of private consumption increases (becomes more negative) with the level of development of the domestic financial sector. That is, the substitution effect of changes in the real deposit rate becomes increasingly important as the domestic financial sector develops.

Fourth, liberalization of the capital account has widely differing effects on private sector demand in our two groups of countries. For the IT EMEs, opening of the capital account has a positive impact on private investment but a negative impact on private consumption.

However, for the MENA EMEs, as capital account openness increases, private consumption rises but private investment declines. Possible explanations for these contrasting results are that the MENA EMEs are, in general, poorer and provide an unfriendly business environment and inadequate institutional support for investment compared with the IT EMEs. Thus greater opportunities for borrowing and lending, through opening of the capital account, tends to promote private consumption rather than private investment in the MENA EMEs, while the opposite appears to be the case for the IT EMEs, possibly due to higher living standards and more conducive business environments. 


\section{REFERENCES}

Achy, Lahcen, 2004, "Financial Liberalization, Saving, Investment and Growth in MENA Countries”, http://129.3.20.41/eps/fin/papers/0411/0411004.pdf.

Aysan, Ahmet, Gaobo Pang and Marie-Ange Veganzones-Varoudakis, 2005, "How to Boost Private Investment in the MENA Countries: The Role of Economic Reforms”, Topics in Middle Eastern and North African Economies, MEEA, Online Journal, pp. 1-15.

Beck, Thorsten, Asli Demirgüç-Kunt and Ross Levine, (2000), "A New Database on Financial Development and Structure," World Bank Economic Review 14, 597-605.

Blejer, Mario I. and Mohsin S. Khan, 1984, “Government Policy and Private Investment in Developing Countries”, IMF Staff Papers, Vol. 31, pp. 379-403.

Boughrara, Adel, 2009, “Monetary Policy Transmission Mechanisms in Morocco and Tunisia”, Economic Research Forum Working Paper No. 460, April, Tunis.

Campbell, John Y. and N. Gregory Mankiw, 1989, "Consumption, Income and Interest Rates: Reinterpreting the Time Series Evidence”, NBER Macroeconomics Annual 1989, Volume 4, pp. 185-246.

Chinn, Menzie D., and Hiro Ito, 2008, “A New Measure of Financial Openness”, Journal of Comparative Policy Analysis: Research and Practice, Vol. 10, pp. 309-322.

Elmendorf, Douglas W., 1996, “The Effect of Interest-Rate Changes on Household Saving and Consumption: A Survey”, Finance and Economics Discussion Series, Board of Governors of the Federal Reserve System (U.S.).

Fischer, Stanley, 1998. “Capital Account Liberalization and the Role of the IMF”, Princeton Essays in International Finance 207, pp. 1-10.

Fischer, Stanley, 2003. “Globalization and Its Challenges”, American Economic Review, Vol. 93, pp. 1-30.

Fry, Maxwell J., 1978, “Money and Capital or Financial Deepening in Economic Development?”, Journal of Money, Credit, and Banking, Vol. 10, pp. 464-475.

Funke, Norbert, 2002, “Stock Market Developments and Private Consumer Spending in Emerging Markets”, IMF Working Paper 02/238.

Giovannini, Alberto, 1983, The Interest Elasticity of Savings in Developing Countries: The Existing Evidence”, World Development, Vol. 11, pp. 601-607.

Greene, Joshua and Delano Villanueva, 1991, "Investment in Developing Countries: An Empirical Analysis”, Staff Papers - International Monetary Fund, Vol. 38, pp. 33-58. 
Gruber, Jonathan, 2006, “A Tax-Based Estimate of the Elasticity of Intertemporal Substitution”, NBER Working Paper No. 11945.

Henry, Peter Blair, 2000a, “Do Stock Market Liberalization Cause Investment Booms?”, Journal of Financial Economics, Vol. 58, pp. 301-334.

Henry, Peter Blair, 2000b, “Stock Market Liberalization, Economic Reform, and Emerging Market Equity Prices”, The Journal of Finance, Vol. 55, pp. 529-564.

Jardak, Tarak and Ewa Wróbel, 2009, “The Monetary Transmission Mechanism in Tunisia: Recent Developments”, Banque Centrale de Tunisie, unpublished manuscript.

Nabli, Mustapha K., 2007, "Long-Term Economic Development Challenges and Prospects for the Arab Countries", Chapter 1 in Mustapha K. Nabli (ed.), "Breaking the Barriers to Higher Economic Growth: Better Governance and Deeper Reforms in the Middle East and North Africa”, The World Bank, Washington, D.C., U.S.A.

Makdisi, Samir, Zeki Fattah and Imed Limam, 2007, "Determinants of Growth in the MENA Countries”, in Jeffrey B. Nugent and Hashem Pesaran (eds.), "Explaining Growth in the Middle East”, Amsterdam; Boston [Mass.]: Elsevier.

McDonald, Donogh, 1983, “The Determinants of Saving Behavior in Latin America”, (unpublished; Washington: International Monetary Fund).

Misati, Roseline Nyakerario, 2007, “Liberalization, Stock Market Development and Investment Efficiency in Africa”, International Review of Business Research Papers, Vol. 3, pp. 183-191.

Misati, Roseline Nyakerario and Esman Morekwa Nyamongo, 2010, "Financial Development and Private Investment in Sub-Saharan Africa", Journal of Economics and Business, doi: 10.1016/j.jeconbus.2010.10.001

Mishra, Prachi, Peter J. Montiel and Antonio Spilimbergo, 2010, "Monetary Transmission in Low Income Countries”, IMF Working Paper WP/10/223, October, International Monetary Fund, Washington, D.C.

Mohanty, M. S. and Philip Turner, 2008, "Monetary policy transmission in emerging market economies: what is new?”, Bank for International Settlements Papers no. 35, pp. 1-59.

Naceur, Samy Ben, Samir Ghazouani and Omran Mohammed, 2008, “Does Stock Market Liberalization Spur Financial and Economic Development in the MENA Region?”, Journal of Comparative Economics, Vol. 36, pp. 673-693.

Neaime, Simon, 2008, "Monetary Policy Transmission and Targeting Mechanisms in the MENA region”, Economic Research Forum Working Paper No. 395, April, Beirut.

Obstfeld, Maurice. 1998. “The Global Capital Market: Benefactor or Menace?”, Journal of Economic Perspectives, Vol. 12, pp. 9-30. 
Reinhart, Carmen M. and Jonathan Ostry, 1995, "Saving and Real Interest Rates in Developing Countries”, University Library of Munich, Germany, MPRA Paper Number 13352.

Reinhart, Carmen M. and Ioannis Tokatlidis, 2003, "Financial Liberalization: The African Experience”, Journal of African Economies, Vol. 12, Supplement 2, pp. 53-88.

Roger, Scott, 2010, “Inflation Targeting Turns 20”, Finance and Development, Vol. 47, pp. 46-49.

Rogoff, Kenneth. 1999. "International Institutions for Reducing Global Financial Instability”, Journal of Economic Perspectives, Vol. 13(4), pp. 21-42.

Rossi Nicola, 1988, “Government Spending, the Real Interest Rate, and the Behavior of Liquidity-Constrained Consumers in Developing Countries”, Staff Papers - International Monetary Fund, Vol. 35, pp. 104-140.

Sarno, Lucio and Mark P. Taylor, 1998, "Real Interest Rates, Liquidity Constraints and Financial Deregulation: Private Consumption Behavior in the U.K.”, Journal of Macroeconomics, Vol. 20, pp. 221-242

Serven, Luis, 2003, "Real-Exchange-Rate Uncertainty and Private Investment in LDCS", The Review of Economics and Statistics, Vol. 85, pp. 212-218.

Summers, Lawrence. 2000. “International Financial Crises: Causes, Prevention, and Cures”, American Economic Review, Vol. 90, pp. 1-16.

Sundararajan, V. and Subhash Thakur 1980, "Public investment, crowding-out and growth: A dynamic model applied to India and Korea”, IMF Staff Papers, Vol. 27, pp. 814-855.

Tun, Wai.U., and Chorng-huey Wong, 1982. "Determinants of Private Investment in Developing Countries.” Journal of Development Studies Vol. 19, pp. 19-36.

Taylor, John, 1995, “The Monetary Transmission Mechanism: an Empirical Framework”, Journal of Economic Perspectives, Vol. 9, pp. 11-26.

Townsend, Robert M., and Kenichi Ueda, 2010, “Welfare Gains From Financial Liberalization”, International Economic Review, Vol. 51, pp. 553-597. 